\title{
FURTHER INVESTIGATIONS ON THE MACROMOLECULAR COMPLEX IN HUMAN BILE
}

\author{
by \\ J. C. M. VERSCHURE, J. DE WAEL AND P. F, MIJNLIEFF \\ with technical assistance from \\ Mrss $\Lambda$. ZWEERS \\ Medical Clinics of the State University, Utrecht \\ and \\ The Van 't Hoff Laboratory, State University, Utrecht (The Netherlands)
}

\begin{abstract}
On his seventieth anniversary, this paper is dedicated to Dr. P. Muller, former head of the Chemical Department of the Medical Clinics of the State University, Utrecht, who discovered and studied, together with A. A. Hymans van den Bergh, the direct and indirect determination of bilirubin.
\end{abstract}

We have demonstrated the existence of a macromolecular complex in human gall bladder bile by means of paper electrophoresis ${ }^{1}$ and with the ultracentrifuge ${ }^{2}$. From its ability to bind a considerable amount of cholesterol and keep it in solution in water, the significance of this complex for bile stone formation was deduced. This paper deals with further investigations concerning this complex, mainly its chemical composition and its place of formation.

\section{A. Synthesis of lecithin-bile salt complexes}

The nucleus of the natural complex is formed by lecithin and bile salts, probably bound by the choleic acid principle of WIELAND AND SORGE ${ }^{3}$ to a very stable compound. Synthesis of such complexes proved to be very simple under conditions as found in human physiology.

Soya bean or egg yolk lecithins were purified by solution in ether and subsequent precipitation with acetone. The dry powder was suspended in water, salt solution or buffer solutions and various bile acids were added. After standing for 48 hours at room temperature, the mixture was centrifuged and the clear supernatant fluid analysed for complex formation by means of paper electrophoresis and the ultracentrifuge. No appreciable complex formation was observed between lecithin and cholic acid or desoxycholic acid respectively, in distilled water, $0.9 \% \mathrm{NaCl}$ solution or buffer solution (McIlvaine) of pH 5.5. However, with both cholic and desoxycholic acid in barbital buffer of $\mathrm{pH} 8.6$ complex formation was evident, but in the case of desoxycholic acid the complex was electrophoretically homogeneous (Fig. I). With sodium glycocholate under the same conditions, no appreciable complex formation was obtained. The same holds for cholesterol and desoxycholic acid in barbital buffer of $\mathrm{pH}$ 8.6: no complex formation was detectable with electrophoresis, nor with the 
ultracentrifuge. This is in disagreement with the early work of ANDREws et al. ${ }^{4}$; they noted complex formation in ethanol. They probably used bile acids, obtained by extraction from natural sources. We now know that these "bile acids" may have contained considerable amounts of lecithin and that consequently they used the lecithinbile salt complex for solution of cholesterol.

None of the lecithin-bile salt complexes could be stained with azocarmine. They showed a faint white fluorescence under ultraviolet light. After they had taken up

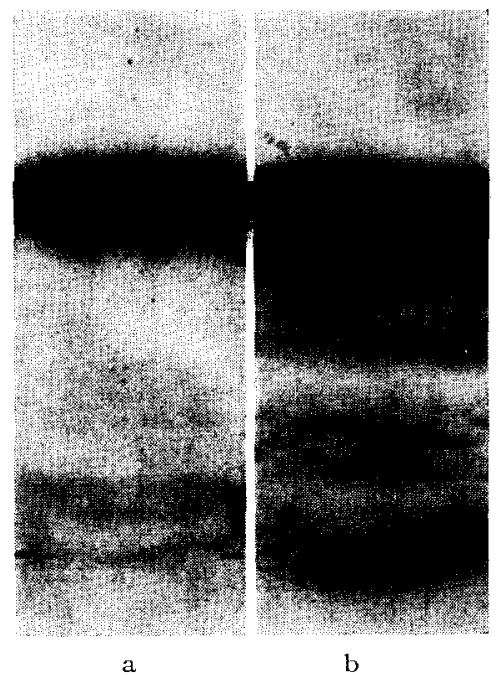

Fig. I. Paper electrophoresis diagrams of the synthetic complexes of lecithin with desoxycholic acid (a) or cholic acid (b). Sudan Black stain.

cholesterol to the saturation point a strong white fluorescence was found. However, the natural complex showed a bright yellow fluorescence and stained intensively with azocarmine. In the ultracentrifuge, the synthetic complex of desoxycholic acid and lecithin behaved like a homogeneous macromolecular substance, whereas the cholic acid-lecithin complex gave a less beautiful curve (Fig. 2).

The electrophoretic mobilities of natural and synthetic complexes were measured according to $\mathrm{DE} \mathrm{WAEL}^{5}$ and their sedimentation constants measured with the Spinco ultracentrifuge. The various differences between the natural complex and the synthetic lecithin-desoxycholate complex are listed in Table I, columns $I$ and 4 . It is obvious that the natural complex and the synthetic lecithin-desoxycholate complex are not identical. With electrophoresis the presence of protein and bilirubin as constituents of the natural complex was found to be probable'. The relation of protein and bilirubin to the complex was therefore studied further.

\section{B. Presence of protein in the natural complex}

The strong staining with azocarmine of the complex, revealed in the paper strips, suggested the presence of a protein. In order to obtain further evidence, spot-tests were performed on the complex band in the filter paper strips, obtained from fresh References p. ${ }_{5} \mathrm{I} 8$ 
gall bladder bile samples. From the qualitative protein reactions only the xanthoprotein reaction proved to be applicable as a spot-test on filter paper. With this reaction, the natural complex band gave positive results, whereas with the synthetic complex, cholesterol or bilirubin no reaction occurred.

It was difficult to prove the presence of protein in the natural complex by means of chemical methods. The complex is intensively coloured by bilirubin, thus preventing direct colour reactions into the solution. Nitrogen is present from various sources: the bile acids are partly conjugated with amino acids. In bile various other proteins are

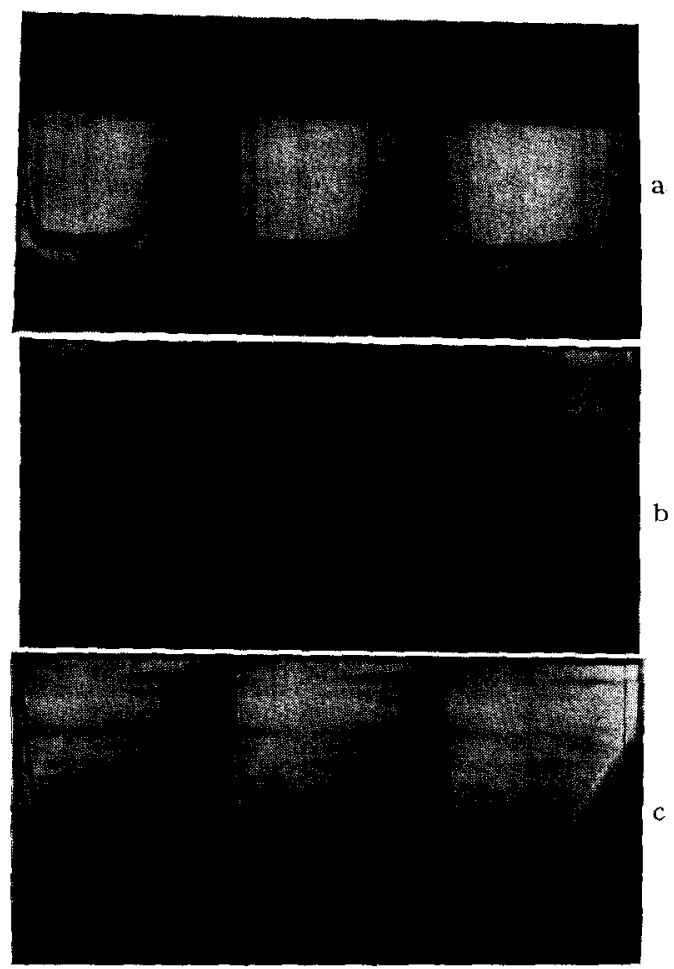

Fig. 2. Ultracentrifuge sedimentation diagrams of (a) lecithin-desoxycholic acid complex; (b) lecithin-cholic acid complex; (c) mixture of cholesterol with desoxycholic acid. No complex formation is noted.

present. Isolation of the natural complex in sufficient quantities without loss of constituents proved difficult. With starch column electrophoresis no satisfying separation was obtained.

We tried to discover whether one or other polypeptide or protein could be attached to the synthetic complex. The desoxycholate-lecithin complex was therefore brought into contact with solutions containing albumin, $\gamma$-globulin, serum proteins, peptone, the other bile proteins, mucoproteins from saliva, insulin and polypeptides obtained by partial tryptic digestion of serum proteins at $\mathrm{pH}$ 8.6. In several series, calcium, magnesium or copper salts were added in such concentrations as are found in gall bladder bile.

With human serum and also with the products of tryptic digestion from albumin Reforonces p. $5 x 8$ 
TABLE I

COMPARISON OF VARIOUS PROPERTIES OF NATURAL BILE COMPLEX, SYNTHETIC COMPLEX AND VARIOUS EXTRACTED PRODUCTS

\begin{tabular}{|c|c|c|c|c|}
\hline & $I$ & 2 & 3 & 4 \\
\hline & $\begin{array}{c}\text { Natural } \\
\text { complex in } \\
\text { gall bladder bile }\end{array}$ & $\begin{array}{c}\text { Isaksson's } \\
\text { extraction } \\
\text { product }\end{array}$ & $\begin{array}{l}\text { Kier's } \\
\text { extraction } \\
\text { product }\end{array}$ & $\begin{array}{l}\text { Synthetic complex } \\
\text { from lecithin } \\
\text { and desoxycholate }\end{array}$ \\
\hline Lipid stain (Swahn) & $+t+$ & $++t$ & $+t+$ & +++ \\
\hline Protein stain & $++t$ & + & + & - \\
\hline Fluorescence & bright yellow & faint yellow to & white & white \\
\hline Xanthoprotein reaction & $t$ & white \pm & \pm & - \\
\hline \multirow{5}{*}{ Electrophoretic mobility } & $10.5 \cdot 10^{-5}$ & $9.9 \cdot 10^{-5}$ & $9.0 \cdot \mathrm{IO}^{-5}$ & $8.9 \cdot 10^{-5}$ \\
\hline & $10.2 \cdot 10^{-5}$ & & & $9.0 \cdot 10^{-5}$ \\
\hline & $9.1 \cdot 10^{-5}$ & & & $8.4 \cdot 10^{-5}$ \\
\hline & $9.0 \cdot 10^{-5}$ & & & plus cholesterol: \\
\hline & $8.5 \cdot 10^{-5}$ & & & $7.8 \cdot 10^{-5}$ \\
\hline mean value & $9 \cdot 5 \cdot 10^{-5}$ & & & $8.8 \cdot \mathrm{ro}^{-5}$ \\
\hline \multirow{14}{*}{$\begin{array}{l}\text { Sedimentation constants } \\
(\text { dilution } 10-36 \times)\end{array}$} & $2.1 \cdot 10^{-13}$ & $2.3 \cdot 10^{-13}$ & $\mathrm{I} .4 \cdot \mathrm{IO}^{-13}$ & $1.8 \cdot 10^{-13}$ \\
\hline & $1.2 \cdot 10^{-13}$ & $2.3 \cdot 10^{-13}$ & $1.4 \cdot \mathrm{ro}^{-13}$ & $2.2 \cdot \mathrm{IO}^{-13}$ \\
\hline & $\mathrm{I} \cdot 5 \cdot 1 \mathrm{O}^{-13}$ & $2.5 \cdot 10^{-13}$ & $1.6 \cdot 10^{-13}$ & I. $7 \cdot 10^{-13}$ \\
\hline & $1.4 \cdot 10^{-13}$ & & $1.3 \cdot 10^{13}$ & $2.6 \cdot 10^{13}$ \\
\hline & $I .5 \cdot 10^{-13}$ & & $1.4 \cdot \mathrm{IO}^{-13}$ & $2.5 \cdot \mathrm{ro}^{-13}$ \\
\hline & $1.8 \cdot 10^{-13}$ & & $1.4 \cdot 10^{-13}$ & \\
\hline & $1.8 \cdot 10^{-13}$ & & $1.5 \cdot 10^{-13}$ & \\
\hline & $1.3 \cdot 10^{-13}$ & & $1.4 \cdot 10^{-13}$ & \\
\hline & $1.4 \cdot 10^{-13}$ & & $1 \cdot 3 \cdot 10^{-13}$ & \\
\hline & $1.4 \cdot 10^{-1 a}$ & & & \\
\hline & $1.4 \cdot 10^{-13}$ & & & \\
\hline & I. $6 \cdot 10^{-13}$ & & & \\
\hline & I. $8 \cdot \mathrm{IO}^{-13}$ & & & \\
\hline & $2.0 \cdot 10^{-13}$ & & & \\
\hline mean value & I. $6 \cdot 10^{-13}$ & $2.4 \cdot 10^{-13}$ & $1.4 \cdot 10^{-13}$ & $2.2 \cdot \mathrm{IO}^{-13}$ \\
\hline
\end{tabular}

or $\gamma$-globulin, some addition of protein to the synthetic complex occurred and some slowly moving lecithin-desoxycholate-protein complexes were demonstrable. Although these complexes differ markedly from the natural bile complex, they show that in principle, the lecithin-bile salt nucleus may take up protein molecules.

\section{Bilirubin as a constituent of the natural complex}

In all cases the natural complex carried considerable amounts of bilirubin ${ }^{2}$, giving a diazoreaction when sprayed with Ehrlich's reagent. There appeared to exist a reciprocal relationship between the bilirubin content of the complex and its ability to take up azocarmine. We therefore thought ${ }^{2}$ that perhaps bilirubin occupies the same sites in the complex molecule as are occupied by the azocarmine.

Direct binding of pure bilirubin preparations to the synthetic complex was unsuccessful. We used bilirubin of Hoffmann-La Roche, dissolved in alkali or ethanol. After addition to the synthetic complex, binding of the bilirubin was studied by means of paper electrophoresis and in the ultracentrifuge. No binding could be detected. In another experiment fistula bile was dialysed against a solution of the synthetic complex. Although a sufficient amount of bile pigments passed into the complex solution, no binding could be observed. However, direct addition of synthetic complex 
to fistula bile resulted in binding all the bilirubin that was present. In the electrophoresis diagrams and in the ultracentrifuge it moved with the same velocity as the complex.

\section{Properties of chemically extracted complexes}

ISAKSSON ${ }^{8}$ extracted a complex with chloroform after freeze-drying gall bladder bile samples. He was the first to recognize this complex as consisting essentially of lecithin and bile acids. We applied his method and studied his extraction product with electrophoresis and the ultracentrifuge. In our hands, freeze-drying of bile had some destructive influence. After solution of the dry powder in a barbital buffer of pH 8.6, an insoluble residue remained in some cases and the diagrams with paper electrophoresis were often less well defined. The various properties of IsAksson's extraction product are listed in Table I, column 2. In some cases, the electrochromograms of the extraction product showed all the characteristics of the natural complex, giving an azocarmine stain, diazoreaction and yellow fluorescence of the complex band. In other samples these characteristics were practically or totally absent. ISAKSSON did not detect protein in his extraction product ${ }^{7}$. The electrophoretic mobility of the extraction product seems to be of the same magnitude as that of the natural complex. The sedimentation constant of ISAKSSON's extraction product is slightly higher than that of the natural complex.

Extraction of gall bladder bile with a mixture of ether, ethanol and acetone I : I : I yielded a complex that was always devoid of its bilirubin. Its electrophoretic velocity was of the same magnitude as that of the natural complex. The band of this extraction product gave a white fluorescence. The characteristic yellow fluorescence of the natural complex seems to be dependent upon the presence of bilirubin in the complex molecule. The azocarmine stain was found positive in the extraction product. Because the extraction mixture was used by $\mathrm{KIER}^{8}$ in his determination of bile acids, the extraction product was further called "Kier's complex". Data collected about this product are listed in Table $I$, column 3 .

It is evident that both extracted complexes stand between the naked structure of the lecithin-bile salt complex and the natural complex of gall bladder bile.

\section{E. Place of formation of the gall bladder-bile complex}

Preliminary studies pointed in the direction of the gall bladder mucosa as the probable site of formation of the natural complex in human gall bladder bile ${ }^{2}$. With concentration up to fivefold, fistula bile samples gave good electrophoresis diagrams but no or only small quantities of the complex were observed. We then concentrated fistula bile samples up to 20 times their original concentration and under these conditions, a complex could be detected in practically all the samples.

In another experiment, gall bladder bile or fistula bile samples were freeze-dried and subsequently solutions were made in barbital buffer to equal concentration of total solids, e.g. ro $\mathrm{g}$ per roo $\mathrm{ml}$. These solutions were compared by means of paper electrophoresis. The amount of complex present in gall bladder bile was always much higher than in fistula bile of the same total concentration. In fistula bile much more of the second bile protein was found. This indicates that the relative concentration of lecithin in gall bladder bile is much higher than might be expected from concen- 
tration only. Furthermore, disappearance of protein from fistula bile seems evident. Addition of lecithin to fistula bile increases the production of complex.

\section{F. Ultracentrifuge diagrams of fistula bile}

Six fistula bile samples obtained from patients after surgery and chosen at random were ultracentrifuged under various conditions as to dilution and ionic strength, and after addition of various constituents. Often two or three peaks are found in the curve. In several cases the gradients were skew. Three typical diagrams are shown in Fig. 3.

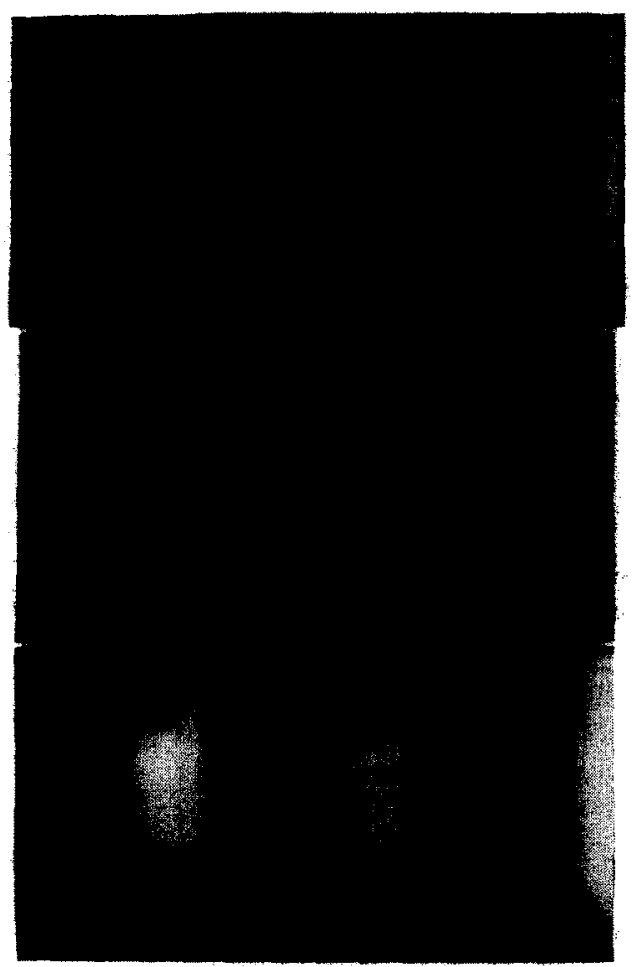

Fig. 3. Ultracentrifuge diagrams of three human fistula bile samples.

From 18 diagrams the following conclusions may be drawn:

r. Complex formation in fistula bile is less well defined than in gall bladder bile. The diagrams show much greater deviations in sedimentation constants. The number of boundaries was in most cases more than one. It is probable that proteins are responsible for one or more gradients in most of the diagrams.

2. The bilirubin tends to move with the slowest moving gradient, and thus must be bound partly to some macromolecule.

3. Under conditions of dilution and ionic strength, comparable to those of gall bladder bile, the components in fistula bile generally tended to show higher sedimentation constants.

4. In 3 out of 6 fistula bile samples, components were noted with sedimentation 
constants falling within the same range as those of the complex found in gall bladder bile.

Concerning the higher sedimentation constants in fistula bile, experiments were carried out with a synthetic complex obtained from lecithin with cholic acid in buffer solution (Fig. I, b). This complex has a much higher sedimentation constant than the synthetic product of lecithin with desoxycholic acid. We found for the cholate complex in buffer solution $S_{20}=(8.0 \pm 1.0) \times 10^{-19} \mathrm{sec}$. After addition of desoxycholic acid to this preparation, most of the complex was changed to a substance with a sedimentation constant of $\mathrm{I.2}_{2} \cdot \mathrm{IO}^{-13}$. Desoxycholic acid seems to compete successfully with cholic acid for positions on the lecithin molecules.

It seems probable from these observations that complex formation starts in fistula bile. These complexes have various properties that may depend upon the varying ratio between cholic and desoxycholic acids. In the gall bladder the conditions for complex formation become optimal. These conditions are not fully understocd. Concentration only is not sufficient. Disappearance of proteins and increase of lecithin contents and desoxycholic acid were found to be necessary.

\section{SUMMARY}

The formation of complexes in human bile was further studied by the preparation of various synthetic complexes and extracts. These were compared for a number of properties with the natural complex of human gall bladder bile. It appeared that protein is probably and bilirubin quite definitely a constituent of the natural complex. Small quantities of the complex or related substances could be detected in fistula bile. Complex formation begins in the fistula bile, but in the gall bladder the conditions for complex formation are optimal. The phenomena cannot be explained by concentration of the hepatic bile alone.

\section{RÉSUMÉ}

Les recherches sur la formation de complexes dans la bile humaine ont été continuées par la préparation de divers complexes et extraits synthétiques. Ceux-ci ont été comparés avec le complexe naturel de la vésicule biliaire en ce qui concerne un certain nombre de leurs propriétés. Il appert que la bilirubine est certainement un constituant du complexe naturel et que celui-ci contient probablement de la protéine. De faibles quantités du complexe et de substances apparentées ont pu être décelées dans la bile de fistule. La formation du complexe commence dans la bile de fistule, mais dans la vésicule biliaire les conditions pour cette formation sont optima. Ces phénomènes ne peuvent pas être expliqués uniquement par concentration de la bile de foie.

\section{ZUSAMMENFASSUNG}

Die Untersuchung der Komplexbildung in der menschlichen Galle wurde durch Herstellung verschiedener synthetischer Komplexe und Extrakte fortgesetzt. Diese wurden in Bezug auf eine Anzahl Eigenschaften mit dem natürlichen Komplex der Gallenblase verglichen. Fs stellte sich heraus, daB das Bilirubin sicher und Protein wahrscheinlich ein Bestandteil des natürlichen Komplexes ist. Geringe Mengen des 
Komplexes und verwandter Verbindungen konnten in der Fistelgalle nachgewiesen werden. Die Bildung des Komplexes beginnt in der Fistelgalle, aber in der Gallenblase sind die Bedingungen für seine Bildung optimal. Diese Erscheinungen können nicht allein durch Konzentration der Lebergalle erklärt werden.

\section{PEЗ}

Образование комплексов в желии человека изучахось приготовлением различных синтетических комплексов и әкстрактов. Производилось сравнение определенных их свойств со свойствами натуральных комплексов желчи человека из желчного пузыря. Оказываетея, что билирувин является компонентом натурального комплекса и, возможно, белка. Небольшие количества комплекса, или родственных веществ, были обнаружены в свишевой желчи. Образование комплекса начинается в свищевой желчи, но опитимальные условия для образования комплекса надо искать в желчном пузыре. Это явление не может быть объяснено только конџентраџией гематической желчи.

\section{REFERENCES}

I J. C. M. Verschure, Clin. Chim. Aclu, 1 (1956) $3^{8 .}$

2 J. C. M. Verschure and P. F. Mijnlieff, Clin. Chim. Acta, I (1956) I 54.

3 H. Wieland and H. Sorge, $Z$. physiol. Chem., 97 (I9I6) I.

4 E. Andrews, R. Schoenheimer and L. Hrdina, Arch. Surg., 25 (1932) 796.

5 J. DE WAEL, to be published.

6 B. Isaksson, Acta Soc. Med. Upsaliensis, 56 (195I) I77; Thesis, Lund, I954.

7 B. IsAKSSON, personal communication.

8 L. C. Kier, J. Lab. Clin. Med., 4o (I952) 755.

Received August 22nd, 1956 